This item was submitted to Loughborough's Research Repository by the author.

Items in Figshare are protected by copyright, with all rights reserved, unless otherwise indicated.

\title{
Book review: 'Bruno Latour. An enquiry into modes of existence: an anthropology of the moderns'
}

PLEASE CITE THE PUBLISHED VERSION

http://dx.doi.org/10.1177/1368431015586640

\section{PUBLISHER}

(c) SAGE Publications

\section{VERSION}

AM (Accepted Manuscript)

\section{PUBLISHER STATEMENT}

This work is made available according to the conditions of the Creative Commons Attribution-NonCommercialNoDerivatives 4.0 International (CC BY-NC-ND 4.0) licence. Full details of this licence are available at: https://creativecommons.org/licenses/by-nc-nd/4.0/

\section{LICENCE}

CC BY-NC-ND 4.0

\section{REPOSITORY RECORD}

Chernilo, Daniel. 2019. "Book Review: 'bruno Latour. An Enquiry into Modes of Existence: An Anthropology of the Moderns'”. figshare. https://hdl.handle.net/2134/18002. 
Book Review. Bruno Latour, An enquiry into modes of existence. An anthropology of the moderns. (Cambridge, Massachusetts: Harvard University Press, 2013, 486 pp., $£$ 29.95, ISBN 978-0674724990).

Daniel Chernilo, Loughborough University D.Chernilo@lboro.ac.uk

One key feature of modern life is the dissatisfaction with modernity's own selfdescriptions. Accounts of these experiences vary greatly, of course, but more often than not they reflect on disappointed expectations and the gaps between 'facts' and 'values' or between 'representation' and 'reality'. Equally modern is the view that modernity can only be described adequately if we do so in its totality and on the basis of a more or less radical claim to originality: historical conditions make it necessary that a new narrative is attempted; previous accounts are to be discarded but now we will succeed in avoiding past mistakes. A sequel to his own We have never been modern, Bruno Latour's most recent book belongs decidedly to this modernist genre in which modernity is treated as a single civilizational complex that is in need of full reconsideration: it is a thoroughly modern attempt to account for the modern dissatisfaction with the modern experience of unfulfilled promises that come out of modernity's own successes and failures. To Latour, the modern world we inhabit exists but not in the way people think it does. It can and ought to be explained objectively but the scientists who have produced these explanations have radically misunderstood what they are doing; it works well, but this is despite our misunderstanding technology as merely a means to an end; it has been beautifully represented in countless works of arts but these are neither the creation of particular authors nor a reflection of their time and place. You and I are real, but 'our' consciousness and bodily constitution are not really ours and tell us anything about our shared humanity.

Let me be more precise. Modernity cannot live up to its core commitments to objective knowledge, individual autonomy, collective solidarity and the mastery of nature because they are based on key category mistakes (17). Subject and object, society and nature, culture and psyche, are all too generic and unspecific and, as such, they prevent us from understanding the real associations, successful constructions and plurality of modes of being that are needed in order to grasp the modern cosmos in its actual complexity. In modernity, therefore, theory and practice not only do not match but contradict one another $(121,165,176,218)$, truths exist because they are relative $(120,280)$, all forms of materiality are fundamentally ideal $(98,106,124)$ and stability requires constant change $(33,102)$. We wrongly treat non-beings as living entities - humans, natural beings and symbolic representations 
$(100-103,119)$ - whilst real beings get no ontological credit: networks of all shapes and forms. The source of most modern conflicts lies in the fact that we care deeply for values we do not fully understand, values that are deployed through institutions that actually undermine them and values that can claim to be absolute only because they are relative vis-à-vis other values $(40-45,94-95,104)$. The price modernity pays for all this cognitive, aesthetic and ultimately ontological confusion may be primarily apparent in the deficiencies of its self-descriptions, but their truly dramatic consequences are paid in the hard currency of the life and death (i.e. the killing, torture and colonisation) of everyone who does not fully partake in modern beliefs $(43,105,152-156)$. Indeed, the moderns themselves are victims of what they have created: by fanatically seeking to put an end to fanaticism, they are obsessed with their own obsessions and alienated in their attempts to overcome alienation. They are unable to see how much of their own everyday life depends on such idols as the objectivity of science, the neutrality of technology, the autonomy of society or the immutability of human nature $(164-171,205,268)$. If we are going to succeed in renarrating the modern modes of existence as a plurality, we then ought to move away from old-fashion ideas, starting by riding ourselves of the venerable homo faber, and be prepared to accept that we humans ourselves are manufactured beings - the homo fabricatus - and the result of dense narratives - the homo fabulator $(230,248)$. The metaphor of the matrix is more than hinted at in Latour's own portrayal: the modern world has taken its shape through a whole array of technological and ontological 'special effects' and is even related to some 'brain lesion' that has not yet been fully diagnosed $(119,202,236,266)$.

If my tone so far sounds a bit unfair, the reader is forewarned that this is what he is going to find over the 486 pages of this monograph. Having made his biggest impact in the field of science and technology studies, it is hard not to read Latour's book as a conscious intervention into the practices and styles of contemporary (social) science; the text's modernism is arguably most apparent in its thoroughgoing desacralisation of scientific idols. First, the book is explicitly introduced as the printed version of a collaborative and still ongoing research project and the point is made that there is a fundamental mismatch between the spirit of a collective and openended research project and a book format that is self-contained, brings knowledge to a relative close and whose authorship remains individual (xix-xxi). Second, because there is also a complete lack of references, citations, or systematic engagement with scholarly literature or empirical materials (in order to find any of this, we ought to consult the electronic platform on which the book is based). Names and titles are referred to but only in passing and with no concessions whatever in terms of the absence of scholarly apparatus in the book itself. Thirdly, there are two writing styles that co-exist in text. On the one hand, there is a narrative made out of the imaginary 
fieldwork notes of a female ethnographer who, armed by her common sense, personal vigour and hard-won experience as a researcher, is painfully trying to come to terms, disentangle, and then explain to the moderns (who are all without exception whites, Europeans and males) the oddities of the matrix they have constructed for themselves. Sometimes the ethnographer speaks for herself, but more often than not Latour becomes the omniscient narrator who reveals for us the intimate bewilderment, excitement and disappointment of her hero's ethnographic journey. The other narrative strand could not be more different and may be depicted as the apodictic style of the analytic philosopher. Most of the book is a systematic treaty that involves a plethora of new words, concepts and plus a thorough redefinition of old ones.

This dual style is the book's first problem because it creates an unfair 'hermeneutical' challenge to the reader: are the book's bold claims to be taken seriously - as the analytical philosopher would surely do - or are they part of the private notes of the ethnographer's diary, in which case we can or even should treat them as metaphors? Given the book's explicit commitment to an idea of rationality as the step-by-step tracing of the concatenations that make things possible (66) - and risking the possibility that this is not meant either - in what follows I do discuss some of its key arguments seriously. As the book offers neither theoretical discussion nor empirical evidence, I concentrate on one example that appears twice in the first part of book $(87-8,111)$. Latour imagines there a philosopher who uses the statement 'the cat is on the mat' as the kind of exemplary speech act whose truth-value as a statement can be ascertained beyond reasonable doubt: the cat is or isn't there. He admits that this is indeed the case at one level but immediately explains that by concentrating on what we have in front of us, and by making it intelligible through an assertive speech act that can be confirmed or rejected, the philosopher is doing something far more consequential: he is blocking from view the peregrinations, the chains of contingent associations, that are needed for the cat to be on the mat at any particular point in time. Let me briefly elaborate on two dimensions where Latour's programme seems to be at its strongest:

(1) The idea of networks is defined through such notions as 'series of associations' (33), 'chains of references' (154) or 'series of instauration' (162). Far more important than ascertaining whether the speech act actually reflects a real state in the world, Latour claims that there are various beings that are actually there; indeed, they are in fact a form of becoming. When the cat is being observed on the mat, this is thanks to the countless associations that were needed and have remained invisible. The cat, the mat and the philosopher all become through their mutual co-constitution in a network and this is used in support of the more radical suggestion that nature, 
society, the individual, language and technology are not autarchic ontological domains but chains of associations. The question of ontology comes explicitly to the fore here because networks, as beings, are in constant change. Latour's ontology of networks requires a conception of time that never stops because only thus can the claims be made that stability resides in change, solidity in flexibility, necessity in contingency, universality in particularity, etc.

(2) The example also offers a window into the book's argument that there is nothing intrinsically 'scientific' in this speech act. Rather than autonomous domains, science and philosophy, nature and society, are modes of existence that become visible through the stable and successful associations Latour describes as networks. For 'the cat is on the mat' to become a scientific, artistic or political statement, we need to explore its constitution as a network and, in this becoming, we are going to find contaminations that come from other domains. These 'external' elements are no residue or unintended effects but essential; these are what differentiate law, politics or science in the traditional sociological sense of a subsystem, a field or a value sphere, and their reconceptualisation as the modes of existence [LAW], [POL], [REP]. Latour's modernism is again visible in this commitment to the conventionally sociological depiction of modern societies as differentiated separate domains - his own preferred term is 'collectives' (296) - but he seeks to separate from this tradition on two grounds: first, because although the different collectives are autonomous, their autonomy is based on their heteronomy; that is, non-legal elements create law, non-political ones create politics, etc. (29-35, 130-149). Secondly, because these collectives are not 'social' in its traditional social scientific sense of being a specific ontological domain (134-137).

Let me now offer three critical remarks that follow from these arguments.

1) I started this review with the proposition there is nothing more modern than the critique of inadequacies in previous accounts of modernity, but Latour's use of the idea of 'the moderns' in the book is too bland and unspecific. Starting arguably with Hobbes - the $17^{\text {th }}$ century is also key to this narrative of modernity $(110,253,260)-$ one key trend in Western thinking is precisely the view that modern ideas of nature, the individual, society and humanity have been misunderstood and ought to be reconstructed. Latour's positive argument is that only the empirical reconstruction of their articulations, mediations, hiatuses and transformation will make the apparent yet misguided solidity and substantiality of society, nature and the individual come to light (223). The claim that the empirical can on its own redefine ontology is bound to raise some eyebrows, and all the more so because the opposite from ontological pluralism actually ensues. Instead of a cosmos that is populated in a 'richer way' (21), 
Latour has effectively flattened even more the modern ontology. The world is now populated by networks and networks alone: only networks are real because they are well constructed, only networks are viable because they speak various languages, only networks allow unstable components to become 'scientific', 'artistic', or 'economic'. The plurality of modes of existence fails to emerge because it gets subordinated to an endless and ontological unspecific flow of networks; all we can learn and experience we learn and experience because it has successfully become real as a network. In our example, 'the cat', the 'is on', 'the mat' and indeed the philosopher himself are all knowable neither in their own right nor as part of the natural, social or individual domains. They are only real if and when they are constructed (or construct themselves) as networks, but even then their status as the 'primary' elements of the network is never accounted for.

2) The most radical proposition in this book is in my view the need for an ontological redefinition of the distinction between humans and nonhumans. Latour does not mince worlds here: humans are the product of their technologies not only in modernity but throughout history (223), they are the product of the arts they create and consume (241-246) and also of the pills they ingest (186-192). Similar to what happens to the argument on the differentiation of various domains, one is also reminded here of Niklas Luhmann's argument that individuals are external to society. But what in Bielefeld counted as a requirement of methodological consistency (one, incidentally, that remains a source of constant epistemological and normative headaches), in Paris has been transformed into a matter of ontology. In our example, this is explicitly taken up: the philosopher, claims Latour, 'forgets' that the there is another 'correspondence, an equally important one for the cat itself: the one that allows it to exist in time $t+1$ after having existed in time t' (87-8). One part of this argument we have encountered already: the required ontological redefinition needs a conception of time that looks at the fluidity of becoming rather than at the stability of being. Even if we accept that a network may do without the distinction between human and non-human, the ontological threshold is now explicit: this has to be ascertained for the cat itself. I should think that the conditions for this ontological redefinition of the distinction between humans and nonhumans are relatively clear: first, the cat would have to care about the philosopher's speech act. To be sure, not all humans care about social scientific research (although they tend to pay attention when they are portrayed in negative fashion) and Latour-the-animal-lover may still want to suggest that the cats do care and it just happens that the rest, non-cats, simply don't get it. But there is also second condition and here we would need catkind to have devised its own enquiry into the modes in which 'philosophers look at how we cats are on our mats'. But it is one thing to accept that the traditional volitional, dispositional, affective and indeed moral connotations of the human are in 
need of (permanent) redefinition and quite another to toy with these notions and then ask that we treat the resulting claims seriously. The very terms in which Latour's enquiry is set require a strong and rather conventional conception of the human: the ethnographer of the moderns, the book's leading character, only has her personal experience and positive personality traits (optimism, resilience, social skills) to bring her task to successful completion. And the intellectual project is explicitly justified as a personal concern with the revival of fundamentalism (156), the misery that the moderns have caused on others and on themselves, the erosion of trust in modern institutions (278-280) and ecological dangers, all of which require Latour to constantly resort back to 'wes', and 'theys' that ultimately care for these kind of problems $(142,268,286)$. Indeed, there is even a normative plea that a change in the ontological status in the relationships between humans and nonhumans is needed as a defence of humanism (291).

3) I end with a possible explanation as to why Latour is compelled to push for this particular ontological argument despite its apparent weaknesses. The theory of the modes of existence overlooks an important distinction of modern social theory; namely, the difference between theory of knowledge and theory of society. Even if increasingly hesitantly, the moderns still claim that science has some predictive capacities. What after Hegel they no longer believe in is that the cognitive operations of science mirror the actual operations of the world they are seeking to understand. To put it differently, explaining how science generates reliable knowledge - the epistemological problem par excellence - does not create a template for understanding how social reality actually is - the ontological problem: the moderns know only too well that increased epistemological certainty is paid in the hard currency of ontological uncertainty. But Latour claims that because laboratory studies are central to understand how the modern world works (89), then science does mirror society at large (253): this is a sociological return to pre-sociological certainty. The empirical depth of science and technology studies will at long last allow us to restore science and technology to their pride of place in society: STS are able to re-explain to the moderns what their modernity consists in because the whole of society is claimed to work in the way we now know science does $(11,70-71,82$, $129,147,164,194)$. This, in turn, leads to the normative claim: the moderns will be all right because for the first time in their history they can reasonably belief in the objectivity of science. It is only the claim on the centrality of science in society that appears to grant plausibility to the ontological redefinition of humans and nonhumans. But whatever else may be taking place in terms of grants, patents, legislations, or even cases of sexual harassment, the fact remains that laboratories are explicitly construed in order to produce the artificial conditions within which new 'beings' can emerge. In order to understand life in the lab, the manipulator of the microscope, the 
microscope itself and the particle under scrutiny may well have to be looked as one network - and here we may follow Latour the ethnographer. But this theory of knowledge does not work as a theory society: the modern scientific laboratory is just not an apt metaphor for understanding family relations, football matches, or universities themselves. The more our ubiquitous technological gadgets are actually becoming one with us in everyday life, the less humans are in of need a reminder practical or otherwise - that they remain the beings who make a difference. 